\title{
Pasture species for drought-prone lower slopes in the South Island high country
}

\author{
R.F. WOODMAN', J.M.KEOGHAN ${ }^{2}$ and B.E. ALLAN ${ }^{2}$ \\ ${ }^{2}$ AgResearch, Tara Hills High Country Research Station, Private Bag, Omarama \\ ${ }^{2}$ AgResearch, Lincoln.
}

\begin{abstract}
One hundred and twenty one cultivars and accessions of conventional and alternative legume, grass and forb species have been assessed over a widely variable lower sunny face landscape mosaic within the semi-arid tussock grasslands. Results are presented for assessments carried out 7-8 years after planting. Caucasian clover, hairy canary clover, birdsfoot trefoil, crown vetch and luceme were the best adapted legume species. By contrast, conventional clover species performed poorly; red and alsike clovers all died and only a few plants of white and subterranean clovers have survived, all within the more favourable areas of the landscape. Cocksfoot, wheatgrass, smooth brome and tall fescue survived well across the landscape mosaic and showed good vigour and survival. Cocksfoot cultivars and accessions had the best combination of agronomic attributes. In contrast, the survival of all perennial ryegrasses, declined markedly since the 3rd year. These results have important implications for the future development of sustainable pastoral systems in drought-prone landscapes.
\end{abstract}

Keywords dryland pasture species, legumes, grasses

\section{Introduction}

Insufficient quality winter-early spring feed is a major constraint to meeting livestock feeding goals in the South Island hill and high country. Lower sunny slopes are the warmest landscape units and therefore have the potential to provide cost-effective feed during this period. However, alegume base is required to enable coolseason active grasses and forbs to perform well.

Lack of pasture species with sufficient drought tolerance to persist and spread, highlight the need for new pasture types to increase production on lower faces (Keoghan 1985). Chapman et al. (1989) reported on the early establishment and drought tolerance of plants in this trial after 2-3 years. This paper deals with the longer term plant persistence, seasonal performance. drought and frost tolerance of this wide range of conventional and alternative pasture plants introduced into a variable lower sunny face landscape mosaic in the semi-arid tussock grasslands after 7-8 years.

\section{Methods and materials}

\section{Experimental area}

The trial was established on a dry subhygrous yellowgrey earth soil (mean annual rainfall $532 \mathrm{~mm}$, altitude $520 \mathrm{~m}$ ) over a widely variable landscape mosaic on lower sunny faces at Tara Hills High Country Research Station, Omarama in September 1984. Climatic conditions during the reported trial period are outlined in Table 1 . The amount of precipitation is even throughout the year but, in summer, high evaporation rates reduce the effectiveness of the rain. There is typically a soil moisture deficit on lower sunny faces from October to April and soil moisture is below wilting point for much of the growing season.

Table 1 Seasonal rainfall and minimum winter temperatures at Tara Hills Research Station, Omarama, for the period $1988-1992$

\begin{tabular}{|c|c|c|c|c|c|}
\hline \multirow[b]{2}{*}{ Year } & \multicolumn{3}{|c|}{ Rainfail } & \multicolumn{2}{|r|}{ Temperature } \\
\hline & $\begin{array}{l}\text { Spring } \\
(\mathrm{mm})\end{array}$ & $\begin{array}{l}\text { Summer } \\
(\mathbf{m m})\end{array}$ & $\begin{array}{l}\text { Autumn } \\
\text { (mm) }\end{array}$ & $\begin{array}{l}\text { Annual } \\
(\mathrm{mm})\end{array}$ & $\begin{array}{l}\text { Winter } \\
\left({ }^{\circ} \mathrm{C}\right)\end{array}$ \\
\hline 1966 & 175 & 156 & 75 & 460 & -1.4 \\
\hline 1969 & 32 & 95 & 176 & 490 & -2.2 \\
\hline 1990 & 97 & 207 & 162 & 490 & -1.5 \\
\hline 1991 & 136 & 126 & 61 & 544 & -2.9 \\
\hline 1992 & & 93 & 54 & & \\
\hline \multicolumn{6}{|l|}{40 year } \\
\hline mean & 133 & 147 & 141 & 532 & -2.1 \\
\hline \multicolumn{6}{|c|}{ Evaporatlon' } \\
\hline \multicolumn{6}{|l|}{30 year } \\
\hline 1 Evaporation & rates taken from & a bolow & dish & & \\
\hline
\end{tabular}


Trial design and measurements

Grass, legume and forb accessions induded in the tial are listed in Table 2: Material included local, $\mathrm{New}$ Zealand and overseas selections. 121 accessions were arranged in a latin square experimental design. Four replicates were placed so as to represent as much of the variation in soil depth. moisture status and resident vegetation cover within the block.
Plants were grown in root trainers in the glasshouse and legumes inoculated.

Introductions were integrated with the resident species by transplanting a row of 25 plants of each selection into each replicate with plants spaced at $20-\mathrm{cm}$ intervals and rows $\mathbf{1 . 5} \mathrm{m}$ apart except where rocky terrain made this impossible. Plantings commenced in spring 1984 and establishment failures were replaced in 1985. Plants were watered regularly following establishment to im-

Table 2 Legumes, grasses and forbs included in the trial an lower sunny slopes at Tara Hills, Omarama

\begin{tabular}{|c|c|c|}
\hline species & Common Name & $\begin{array}{l}\text { Number of } \\
\text { Accesslons }\end{array}$ \\
\hline \multicolumn{3}{|l|}{ Legumes } \\
\hline Trifollum repens & White clover & 18 \\
\hline T. subterraneum & Subterranean clover & 9 \\
\hline T. pratense & Red clover & 6 \\
\hline T. hybridum & Alsike clover & 7 \\
\hline T. ambiguum & Caucasian clover & 2 \\
\hline T. balansae & Balansa dover & 3 \\
\hline T. medium & Zig-zag clover & 1 \\
\hline Lotus comicularus & Birdstoot trefoil & 8 \\
\hline \multicolumn{3}{|l|}{ L. cornicularus $x$} \\
\hline L. pedunculatus & Lotus hybrid (G4712) & 1 \\
\hline L. pedunculatus & Lotus major & 3 \\
\hline Medicago sativa & Lucerne & 5 \\
\hline M. arborea & Tree medic & 1 \\
\hline Omithopus spp. & Serradella & 2 \\
\hline Onobrychis vicifolia & Saintoin & 1 \\
\hline Astragalus cicer & Milk vetch (Lutana) & $i$ \\
\hline C. varia & Crown vetch (G34) & 1 \\
\hline Dorycnium pentaphyllum & Prostrate Canary clover & 1 \\
\hline D. hirsutum & Hairy Canary clover & 1 \\
\hline Lupinus polyphyllus & Russell Iupin & 1 \\
\hline Chamaecytisus palmensis & Tagasaste (tree lucerne) & 1 \\
\hline Hedysarum coronarium & Sulla & 1 \\
\hline \multicolumn{3}{|l|}{ Grasses } \\
\hline Lollum perenne & Perennial ryegrass & 15 \\
\hline L. multiforum & Italian ryegrass & 2 \\
\hline Dactylis glomerata & Cocksfoot & 5 \\
\hline D. woronowll & & 1 \\
\hline Bromus willdenowil & Prairie grass & 2 \\
\hline B. inetmis & Smooth brome (Grasslands Tiki) & 1 \\
\hline B. marginatis & Upland brome (Grasslands Hakari) & 1 \\
\hline B. scoparlus & Annual bmme & 1 \\
\hline B. stamineus & Grazing brome (Gala) & 1 \\
\hline Agrostis castellana & Dryland browntop & 1 \\
\hline Festuca arundinacea & Tall fescue & 4 \\
\hline F. rubra & Creeping red fescue & 2 \\
\hline - Cynosurus cristanus & Crested Dogstall & 1 \\
\hline Elytrigia intermedia & Pubescent wheatgrass (Luna) & 1 \\
\hline Holcus lanatus & Yorkshire fog & 2 \\
\hline Phalaris aquatica & Canary grass (Grasslands Maru) & 1 \\
\hline Secale montanum & Mountain rye & 2 \\
\hline Poa pratensis & Kentucky bluegrass & $i$ \\
\hline \multicolumn{3}{|l|}{ Forbs } \\
\hline Sanguisorba minor & Sheep's burnet & 1 \\
\hline Cichorium intybus & Chicory & 1 \\
\hline Achillea millifolium & Yarrow & 1 \\
\hline
\end{tabular}


prove initial survival. Initial fertiliser treatment was $200 \mathrm{~kg} / \mathrm{haSulphur}$ Super Extra $(27 \% \mathrm{~S})$ followed by 100 $\mathrm{kg} /$ ha every second year. Molybdenum as sodium molybdate was sprayed on after transplanting.

The trial was fenced to exclude stock and rabbits for the first four years, apart from mob grazing twice a year by sheep. From autumn 1989 the fencing was removed to provide the trial with the same management as the block as a whole. The block is used for lambing and intermittently grazed again in late summer and in winter with hoggets.

Plants were regularly assessed for survival, seasonal performance, drought and frost tolerance. Plant counts were recorded for survival data and other agronomic characters were assessed by visual scoring on a 1 - 5 scale: where $1=$ extremely poor; and $5=$ excellent. An "overall performance" was obtained by averaging the ranked values from survival, seasonal performance and drought tolerance. Scott \& Maunsell (1986) concluded that for winter feed based on permanent grass species the main requirement is for adequate pre-winter yields and that small differences in herbage quality between the species from frosting is a lesser consideration and on this basis frost tolerance data were excluded from the overall performance assessment.

\section{Data analysis}

Plant survival data was arranged into major species groups, for example, cocksfoots. ryegrasses. white clovers. lucemes and as plant survival was recorded as count data it was analysed by applying a generalised linear model to determine the variances and standard errors of the group means. Analysis of variance was used for the remaining scored data to determine SED's between any two specified means.

\section{Results}

Seasonal performance data and ranking of surviving plant types within the trial are given in Tables 3 and 4 .

Legumes

Legumes with the best survival were Monaro Caucasian clover (Trifoliumambiguum). some cultivars and accessions of birdsfoot trefoil (Lotus corniculatus), hairy canary clover (Dorycnium hirsutum). G34 crown vetch (Coronilla varia) and Oranga luceme.

Only a few white clover plants survived within a single replicate from 2 of the 18 cultivars and accessions included in the trial. Other conventional clovers such as alsike and red clover cultivars and accessions did not survive and subterranean clovers showed poor persistence.
The caucasian clover cultivar Monaro had the best overall performance rating (Table 3) showing good plant survival, drought tolerance and seasonal vigour. The eight birdsfoot trefoil cultivars and accessions included in the trial performed well. In particular, plants were drought tolerant, had high autumn vigour, and good retention of green herbage into winter. G34 crown vetch ranked highest for survival and spring vigour and showed excellent drought tolerance (rank 2). but its autumn vigour was poor (rank 17=). Hairycanaryclover plants survived well, and were extremely drought tolerant (rank 1).

\section{Grasses and forbs}

All cocksfoots (Dactylis species) included in the trial performed well. Overall performance. plant survival and vigour ranked highly for all cocksfoots across the entire landscape mosaic (Table 4). Some overseas cocksfoot accessions performed as well as New Zealand bred cultivars and accessions. Luna pubescent wheatgrass (Elytrigia intermedia), Grasslands Tii smooth brome (Bromus inermis), the tall fescues (Festuca arundinacea) T1327 (Grasslands selection) and Aronde all showed a good overall performance ranking. A perennial ryegrass (Lolium perenne) ecotype from the lower sunny facing slopes at Tara Hills Research Station and PG2. a Pyne Gould Guinness selection from Marlbrough. showed moderate plant survival, despite a decrease of over $50 \%$ in their plant numbers since 1987-88. Most other ryegrasses had poor plant survival and vigour across the trial area. Grasslands Maru phalaris (Phalaris aquatica) persisted only on the most favourable replicate of the trial where its overall performance was excellent. Sheep's burnet (Sanguisorba minor) performed well and it appears highly suited to the landscape variation. Its survival was high and plants combined good drought tolerance with excellent autumn vigour and frost tolerance to provide green herbage into winter.

\section{Discussion}

These longer term results (Table 3) have confiied the promise (Chapman et al. 1989) shown by caucasian clover, birdsfoot trefoil, crown vetch and hairy canary clover as alternative legumes suitable for drought-prone lower sunny faces.

Caucasianclover. ranked 1 overall, is arhizomatous perennial that although slow to establish, is capable of becoming a general sward component after 5 years (Scott 1985). Early growth is concentrated in the development of stout taproots and a large network of rhizomes, and because its growing points are protected underground, it shows good drought tolerance and abil- 
Table 3 Overall perfomance, survival and seasonal vigour of legumes with mean plant survival $210 \%$ on lower sunny slopes at Tara Hills, Omarama.

\begin{tabular}{|c|c|c|c|c|c|c|c|c|c|c|c|c|}
\hline \multirow[t]{2}{*}{ Legume } & \multicolumn{2}{|c|}{$\begin{array}{c}\text { Overall } \\
\text { performance }\end{array}$} & \multicolumn{2}{|c|}{$\begin{array}{l}\text { Plant } \\
\text { survival }\end{array}$} & \multicolumn{2}{|c|}{$\begin{array}{l}\text { Spring } \\
\text { vigour }\end{array}$} & \multicolumn{2}{|c|}{$\begin{array}{l}\text { Drought } \\
\text { tolerance }\end{array}$} & \multicolumn{2}{|c|}{$\begin{array}{l}\text { Autumn } \\
\text { vigour }\end{array}$} & \multicolumn{2}{|c|}{$\begin{array}{c}\text { Frost } \\
\text { tolerance }\end{array}$} \\
\hline & Rank & Score & Ran & k Score & Rank & Score & Rank & Score & Rank & Score & Rank & Score \\
\hline \multicolumn{13}{|l|}{ T. amblguum } \\
\hline $\begin{array}{l}\text { 'Monaro' } \\
\text { L. Corniculatus } \\
\text { 'Mackenzie selection }\end{array}$ & 1 & 3.00 & 2 & 9.25 & 2m & 4.59 & $5=$ & 4.50 & $4=$ & 2.25 & $3=$ & 3.50 \\
\hline $\begin{array}{l}\text { \$2086' } \\
\text { L. corniculatus }\end{array}$ & 2 & 3.59 & 8 & 7.50 & $2=$ & 4,50 & $5=$ & 4.50 & $2=$ & 2.50 & 2 & 3.75 \\
\hline $\begin{array}{l}\text { Vlking' } \\
\text { D. hirsutum }\end{array}$ & 3 & 4.00 & 7 & 5.50 & 8 & 4.00 & $2=$ & 4.75 & $2=$ & 2.50 & $3=$ & 3.50 \\
\hline $\begin{array}{l}\text { 'Hairy canary clover' } \\
\text { C. Varia }\end{array}$ & 4 & 4.25 & 4 & 8.00 & $4=$ & 4.25 & 1 & 5.00 & $9=$ & 1.75 & $8=$ & 2.50 \\
\hline $\begin{array}{l}634^{\prime} \\
\text { L. corniculatus }\end{array}$ & 5 & 5.25 & 1 & 15.00 & 1 & 5.00 & $2=$ & 4.75 & & 0.50 & $5=$ & 3.25 \\
\hline $\begin{array}{l}\text { 'Empire selection' } \\
\text { L. Corniculatus }\end{array}$ & 8 & 8.50 & 3 & 8.25 & 7 & 3.59 & 7 & 3.25 & 9 & 1.75 & $5=$ & 3.25 \\
\hline $\begin{array}{l}\text { 'Granger' } \\
\text { L. corniculatus }\end{array}$ & 7 & 7.00 & 14 & 3.00 & $4=$ & 4.25 & $2=$ & 4.75 & $9=$ & 1.75 & 1 & 4.00 \\
\hline $\begin{array}{l}\text { 'S1035' } \\
\text { L. corniculatus }\end{array}$ & 8 & 8.75 & 11 & 3.75 & 8 & 3.25 & $9=$ & 2.75 & 7 & 2.00 & 7 & 2.75 \\
\hline $\begin{array}{l}\text { Vega It } \\
\text { L. corniculatus }\end{array}$ & 9 & 9.25 & 15. & 2.25 & $12=$ & $=2.25$ & $9=$ & 2.75 & 1 & 2.75 & & -2.00 \\
\hline $\begin{array}{l}\text { Maltland selection' } \\
\text { M. satva }\end{array}$ & 10 & 10.25 & 8 & 4.75 & 101 & 12.50 & 11 & 2.25 & 12 & 1.50 & $\&$ & 2.50 \\
\hline $\begin{array}{l}\text { Wairau' } \\
\text { M. sativa }\end{array}$ & 11 & 10.50 & 12. & 3.25 & 14 & 2.00 & $12=$ & 2.00 & $4=$ & 2.25 & & $=1.25$ \\
\hline $\begin{array}{l}\text { 'Grasslands Oranga' } \\
\text { D. pentaphyllum }\end{array}$ & 12 & 11.25 & 5 & 7.75 & $15=$ & - 1.75 & $21=$ & - 1.25 & 4= & 2.25 & & 1.50 \\
\hline $\begin{array}{l}\text { 'Prostrate canary clover' } \\
\text { M. sativa }\end{array}$ & 13 & 12.59 & 12 & 3.25 & $10=$ & 2.50 & 8 & 3.00 & 20 & 10.0 & & $=2.00$ \\
\hline $\begin{array}{l}\text { ML318 } \\
M . \text { sativa }\end{array}$ & $14=$ & 13.25 & 10 & 4.00 & $15=$ & $=1.75$ & 211 & 1.25 & $7=$ & 2.00 & & $=1.25$ \\
\hline 'CRD 3E, $A_{1} \times$ Washoe $A$, & $14=$ & 13.25 & 9 & 4.25 & $18=$ & $=1.50$ & 12 & $=2.00$ & & $=1.00$ & 12 & 1.75 \\
\hline Error Mean Square & & & & & & 0.718 & & 0.455 & & 1.037 & & 0.295 \\
\hline
\end{tabular}

ity to withstand harder grazing by stock, rabbits and insect damage. Although there is limited information in New Zealand on the growth habit and management of Monaro, this legume has been under grazing assessment on amid-altitude shady face at Tara Hills since 1985 and to date is the most promising legume in terms of persistence and spread under both late spring/summer rotational grazing and continuous stocking. Birdsfoot trefoil, Dorycnium hirsutum and crown vetch showed good palatability to grazing stock, drought tolerance and exceptional persistence in the presence of pests. We concur with Scott (1985) and Wills et al. (1989) that these species are well suited to the severe environmental conditions of the MacKenzie Basin and Central Otago.

Conventional clover species performed poorly in this trial. None of the 12 red clover (Trifolium pratense) cultivars or accessions survived after 1987 despite the lax grazing of the trial (Chapman et al. 1989). The results confii the lack of long-term persistence of this species in the high country (Scott 1985). None of the 7 accessions of alsike clover included in the trial persisted longer than 5 years. White clover cultivars and accessions performed poorly with only a few plants from a small proportion of the group surviving within the more favourable area of the landscape. In this trial, subterranean clover showed poor survival despite the variation in maturity and hard seediness within the group. However its place in other areas of the high country must be further investigated. Some luceme cultivars performed well in this trial and the species has been recognised as a legume suited to this environment (Douglas et $\boldsymbol{a l}$. 1987). However, other luceme accessions showed poor persistence with a noteable decrease in survival since 1987-88. Rows of spaced plantings in the trial area formed "islands" of palatable. green herbage, providing potential targets for selective utilisation by animal 
Table 4 Overall performance, survival and seasonal vigour of grasses and forbs with mean plant survival $220 \%$ on lower sunny slopes at Tara Hills, Omarama.

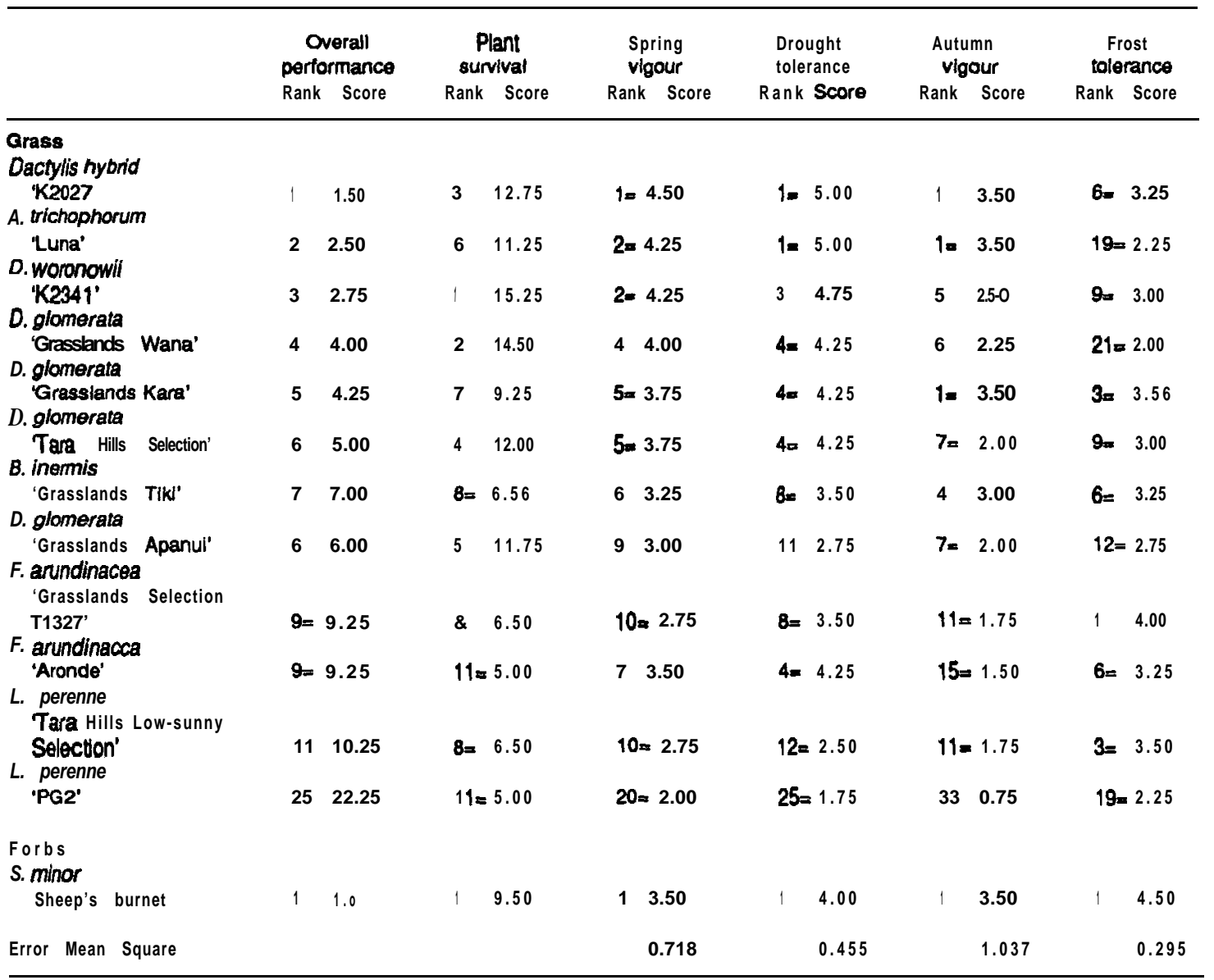

(eg rabbits) and insects. For example, Chapman et al. (1989) reported severe insect damage to lucemes in the trial by the larval of the leaf-roller moth Eurythecta zelaea.

Cocksfoot accessions were well adapted grasses across the landscape mosaic of the trial. The commercially available cultivars Grasslands Wana, Grasslands Kara, the superseded cultivar Apanui and a Tara Hills ecotype representing surviving Apanui plants from an old trial at Omarama Station all performed particularly wellunder the described grazing management. Dactylis woronowii, a cocksfoot of Mediterranean origin, performed as well as any of the New Zealand cocksfoots, supporting evidence from earlier plant introduction trials in the high country (Douglas 1974; Scott 1985). Apanui does not persist where dry sunny slopes are intermittently grazed during the winter and continuously stocked after lambing in early October until mid
November (Allan \& Chapman 1987). Wana cocksfoot is more persistent under continuous stocking (Lancashire \& Brock 1983) and is a good alternative cocksfoot under such conditions. In this trial, the hybrid cocksfoots, for example Kara, appear to be more vigorous in situations where stock are continuously grazed for only part of the spring or autumn growing Period.

Luna wheatgrass, Grasslands Tiki smooth brome, two tall fescues and sheep's burnet were among the other pasture grasses and forbs showing persistence, vigour and consistency across the landscape and have long been recognised as species having good potential in Central Otago and the MacKenzie Country (Douglas 1970, 1974). Despite low initial establishment, plants are Persisting across all four replicates. Poor initial establishment of Grasslands Maru phalaris in three replicates meant that assessment of its performance was limited, however, where its establishment was good, its ability to 
persist and provide winter feed was most encouraging. Grasslands Matua prairie grass failed to persist, despite good initial establishment (Chapman et al. 1989) and no plants remain.

Perennial ryegrasses were low in persistence and vigour despite good initial establishment. Ryegrass plant numbers generally declined markedly since the 1987-88 assessment. However, ryegrass dominates the vegetation on these lower faces at Tara Hills (Allan \& Chapman 1987), so the superior performance of the Tara Hills low sunny ecotype is not surprising. Marathon ryegrass. which previously showed promise, persisted poorly. Winter temperatures and seasonal rainfall, particularly in spring and autumn, were well below average at Tara Hills from 1988-92 (Table 1). Cold temperatures and dry conditions (Allan 1985) are likely to have had some influence on the persistence of ryegrasses over this period.

Commercial seed quantities of many of these alternative pasture species remain unavailable and seedfirms must be encouraged torapidly make available sufficient quantities, since farmer demand in the high country has never been greater.

\section{ACKNOWLEDGEMENTS}

R. Hardie and M.A. Jansen for technical assistance, and P.D. Johnstone for statistical advice.

\section{REFERENCES}

Allan, B .E. 1985. Grazing effects on pasture and animal production from oversown tussock grassland. Proceedings of the NZ Grassland Association 46: 119-125.

Allan, B.E.; Chapman, H.M. 1987. Oversown tussock country: Lessons from 30 years of improvement and management on Tara Hills. Proceedings of the NZ Grassland Association 48: 77-81.

Chapman, H.M.; Keoghan, J.M.; Cossens. G.G.; Allan, B.E.; Littlejohn. R.P. 1989. Promising pasture species for drought prone lower slopes in the South Island highcountry. Proceedings of the NZAgronomy Society 19: 77-84.

Douglas, J. 1970. The Cockayneplots of Central Otago. Proceedings of the NZ Ecological Society 17: 1824.

Douglas, J.A. 1974. A review of the grass species introduction into the tussock grassland of the South Island of New Zealand. Proceedings of the $\mathrm{NZ}$ Grassland Association 35: 234-239.
Douglas, M.H.; Brash, D.W.; Barratt, B.I.P.; Keoghan. J.M. 1987. Successful luceme growing in inland Otago. Proceedings of the NZ Grassland Association 48: 193-197.

Keoghan. J.M. 1985. MAP research on alternative pasture species, cultivars and lines for southern South Island hill and high country. Proceedings of the 1985 Hill and High Country Seminar - Centre for Resource Management Special Publication No.4 Lincoln College: 51-57.

Lancashire, J.A.; Brock, J.L. 1983. Management of new cultivars for dryland. Proceedings of the NZ Grassland Association 44: 61-73.

Scott, D. 1985. Plant introduction trials: genotypeenvironment analysis of plant introductions for the high country. NZjournal of experimental agriculture 13: 117-127.

Scott, D.; Maunsell, L.A. 1986. Winter feed quality of some grasses in the high country. NZ journal of experimental agriculture 14: 19-24.

Wills, B.J.; Begg; J.S.C.; Sheppard, J.S. 1989. Dorycnium and other Mediterranean species - their use for forage and soil conservation in semi-arid environments of New Zealand. Proceedings XIV International Grassland Congress, Nice, France. 1517-1518. 